\title{
What sets lower limits to phytoplankton stocks in high-nitrate, low-chlorophyll regions of the open ocean?
}

\author{
Suzanne L. Strom ${ }^{1, *}$, Charles B. Miller ${ }^{2}$, Bruce W. Frost ${ }^{3}$ \\ 'Shannon Point Marine Center, Western Washington University, 1900 Shannon Point Rd, Anacortes, Washington 98221, USA \\ ${ }^{2}$ College of Ocean and Atmospheric Sciences, Oregon State University, Corvallis, Oregon 97331-5503, USA \\ ${ }^{3}$ School of Oceanography, Box 357940, University of Washington, Seattle, Washington 98195, USA
}

\begin{abstract}
Phytoplankton biomass in high-nitrate, low-chlorophyll (HNLC) ocean regions exhibits a pronounced stability: variation occurs only within a narrow range of values. The magnitude of this variation has profound ecological and geochemical consequences. While mechanisms believed to set the upper limits to HNLC phytoplankton biomass (iron limitation, microherbivore grazing) have received much recent attention, mechanisms setting the lower limits are largely unknown. The demonstrated importance of planktonic micrograzers, largely protists, in removing phytoplankton biomass in HNLC regions suggests that micrograzer behavioral and physiological capabilities may hold the key. This will be the case at any level of phytoplankton cell division greater than zero, regardless of the extent of growth rate limitation by resource (e.g. iron, light) availability. Indeed, HNLC plankton dynamics models almost universally include several biological responses that set lower phytoplankton biomass limits and confer temporal stability, including substantial feeding thresholds, zero micrograzer metabolic costs, and no micrograzer mortality at low food levels. Laboratory observations of these same biological responses in protist grazers are equivocal. There are no direct observations of substantive feeding thresholds, and many heterotrophic protists exhibit significant rates of respiration and mortality (cell lysis) at very low food levels. We present several candidate explanations for the discrepancy between laboratory observations and model biological 'requirements'. Firstly, laboratory-derived rate measurements may be biased by use of species and prey concentrations that are not representative of HNLC communities. Secondly, model micrograzer features may be a proxy for other stabilizing phenomena such as spatial heterogeneity ('patchiness') or carnivory (top-down control of microherbivores), though a logical analysis indicates that neither is likely to provide robust stabilization of lower phytoplankton biomass limits. Lastly, the highly plastic feeding capabilities of protist grazers, which include switching between phytoplankton and alternative prey such as bacteria, detritus, and other microherbivores, are a probable locus for stabilization of biomass limits. The extent to which such behavioral plasticity functions on the level of individuals or of species assemblages is unknown. We advocate a coupled modeling and experimental approach to further progress in understanding this key feature of HNLC ecosystems.
\end{abstract}

KEY WORDS: Planktonic food webs · Grazers · Feeding behavior - Plankton dynamics models · Microzooplankton Phytoplankton

\section{CONCEPTUAL OVERVIEW}

High-nitrate, low-chlorophyll (HNLC) ocean regions (Chisholm \& Morel 1991) are characterized by low, stable phytoplankton standing stocks which rarely

\footnotetext{
•E-mail: stroms@cc.wwu.edu
}

deplete nitrate, phosphate or silicate in the upper water column to growth-limiting levels. Oceanographers have sought in recent decades to understand these 'balanced' pelagic ecosystems, particularly the phenomena that prevent blooms (e.g. Martin et al. 1989, Miller et al. 1991, Price et al. 1994). Current understanding includes both resource and grazer limitation. Phytoplankton cell size is restricted by iron limitation, 
the small cells are accessible to grazing by protists, and the high growth potential of these consumers ensures they will always overtake and suppress increases in phytoplankton stock. This was termed the 'SUPER synthesis' by workers who studied the subarctic Pacific (Frost 1993, Miller 1993) and the 'ecumenical iron hypothesis' in respect to HNLC regions generally (Morel et al. 1991j. The iron-limitation aspects of this explanation seem well supported by the first and second IRONEX studies in the eastern equatorial Pacific (Martin et al. 1994, Coale et al. 1996), where iron injections large enough to remain coherent for several days produced increases of chlorophyll well above the regional norm and phytoplankton communities dominated by large diatoms. Balance of phytoplankton growth by protist grazing continues to be well supported by HNLC field comparisons (Landry et al. 1997).

The recent focus on blooms and their prevention is but one side of the issue of phytoplankton biomass regulation. Equally important as the question 'Why is there no more phytoplankton in these regions replete with macronutrients?' is the question 'Why is there no less?' In the subarctic Pacific, for example, mixed layer chlorophyll a levels rarely drop below $0.15 \mathrm{\mu g} \mathrm{l}^{-1}$ (Fig. 1A). For the equatorial Pacific, long observational time-series do not exist, but euphotic zone chlorophyll a data from JGOFS EqPac cruises (Fig. 2) show a similarly firm lower boundary at about $0.1 \mathrm{\mu g} \mathrm{l}^{-1}$. This is important in part because the minimum phytoplankton biomass, in conjunction with turnover rate, sets minimum levels of primary production, $\mathrm{CO}_{2}$ utilization, and upper trophic level biomass. It is also important to our understanding of HNLC systems, since gross depletion of phytoplarkikton in pelagic trophodynamic models (Steele 1974, Steele \& Henderson 1992) leads to large oscillations in standing stocks (limit cycles) and eventually to nutrient depletion, neither of which is observed in these systems. Without an understanding of the mechanisms setting the lower limits to phytoplankton stock on both seasonal and short-term time scales, our understanding of HNLC systems is incomplete.

In synthesizing data from earlier work in the subarctic Pacific, we felt we understood the primary controls on phytoplankton biomass, as described above. Both correct minima and correct short-term periodicity of subarctic Pacific chlorophyll have been reproduced in a model of phytoplankton-micrograzer interaction (Frost 1993). Since then, the accumulation of data on protist grazing behavior and physiology, in comparison with model formulations, has raised doubt about how phytoplankton biomass minima are sustained. In this paper, we demonstrate that there is a serious mismatch between the capabilities of protist grazers as de- manded by HNLC plankton dynamics models and as demonstrated in laboratory investigations. Our goal is to use this mismatch to explore candidate explanations for the maintenance of lower biomass limits, and to suggest a way forward for both observationalists and theoreticians.

\section{MICROGRAZERS: MODEL THEORY VERSUS OBSERVATION}

Both theoretical arguments (Cullen 1991, Banse 1992, Frost 1993, Sherr \& Sherr 1994, Fasham 1995) and observations (Strom \& Welschmeyer 1991, Landry et al. 1993, 1995, Verity et al. 1993, Froneman \& Perissinotto 1996) suggest that grazing is the primary loss to the phytoplankton crop in the open ocean. Recent research shows that, even during the diatom-dominated portion of the North Atlantic spring bloom, substantially more of the primary production is lost to grazing than to sinking (summarized by Lochte et al. 1993). A picture is emerging in which, for a range of oceanic systems, losses other than grazing (advection, diffusion, sinking, viral lysis) are simply too low or episodic to balance even modest phytoplankton growth. Thus, since grazers are the principal removers of phytoplankton, grazer feeding rates and standing stocks must be the primary determinants of phytoplankton biomass minima in oceanic systems.

It is important to realize that removal processes (e.g. grazer biology) hold the key to phytoplankton biomass minima as long as phytoplankton cell division is occurring. This is true regardless of the degree to which phytoplankton growth rates are limited by resource availability. For example, in the eastern equatorial Pacific, variations in upwelling rate control delivery of iron to the upper water column, leading to variations in community structure and cell division rates of phytoplankton (Murray et al. 1994, Landry et al. 1997). This influences (though it does not solely dictate) the upper limit of phytoplankton chlorophyll concentrations that can be reached (contrast Fig. 2 lower panels). However, as illustrated by Figs. 1B \& 2, over time scales of hours to days phytoplankton occupy a 'biomass space' that has a variable, non-zero lower boundary. As shown in the equatorial Pacific 'chemostat model' of Frost \& Franzen (1992), this lower boundary is determined by the degree to which cells are removed, regardless of the rates of resource supply and phytoplankton cell division.

In that they assign this key removal role to grazers, most current pelagic trophodynamic models correctly reflect observation. Sensitivity analyses of many such models (Steele 1974, Frost 1991, 1993, Moloney \& Field 1991 indicate that parameters describing the phyto- 


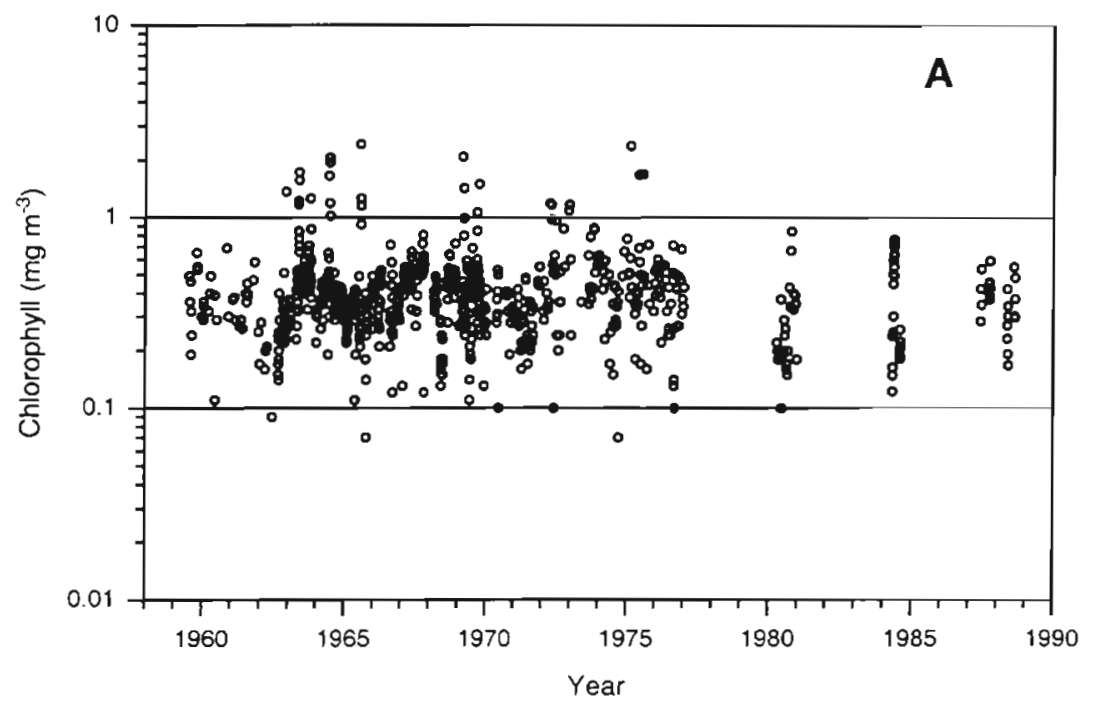

Fig. 1. Water column chlorophyll a concentrations from subarctic Pacific (Stn PAPA: $50^{\circ} \mathrm{N}, 145^{\circ} \mathrm{W}$ ) during (A) 1959 to 1988 (surface values) and (B) May 1988. Surface chlorophyll a data from 1959 to 1976 based on data in McAllister et al. (1959), McAllister (1962), and Stephens (1964, $1966,1968,1977)$; 2 very high values in 1975 (21 June, 26 October) excluded from analysis because of lack of supporting evidence from either subsurface depths or preceding and subsequent dates. Source of other surface data: 1980 (C. B. Miller unpubl.); 1984 (C. J. Lorenzen unpubl. data report); 1987 and 1988

(N. A. Welschmeyer pers. comm.)

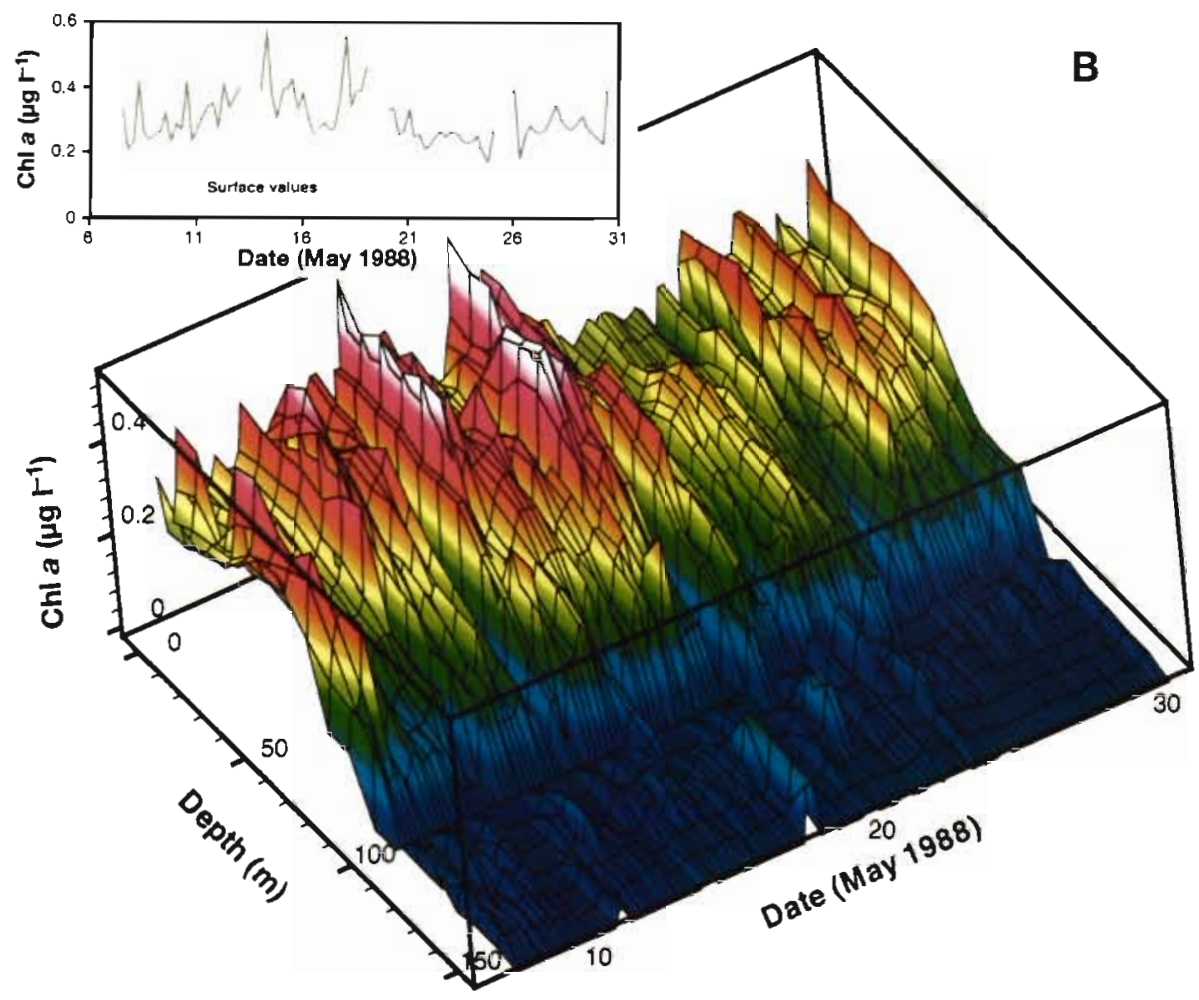

plankton-herbivore relation determine both the maximal and minimal phytoplankton stock levels. Based on experimental data, most of it from studies of copepods, the relationship (often termed a 'functional response') between herbivore grazing and phytoplankton concentration is most commonly modeled with a hyperbolic function such as a Michaelis-Menton or Ivlev curve: grazing increases with prey concentration to a maximum, above which prey concentration grazing is saturated (Fig. 3A,B, solid lines). However, models with such simple functional response curves typically undergo large fluctuations, phytoplankton are grazed to unnaturally low levels, and dramatic, unrealistic limit cycles in all variables ensue (e.g. Franks et al. 1986).

In nature, some aspect of HNLC ecosystems provides a refuge for phytoplankton, preventing reduction to levels low enough to set off expanding limit cycles. In Frost's (1993) subarctic Pacific model this was represented by a grazing threshold, $P_{0}$ (Fig. $3 \mathrm{~A}, \mathrm{~B}$, short- 


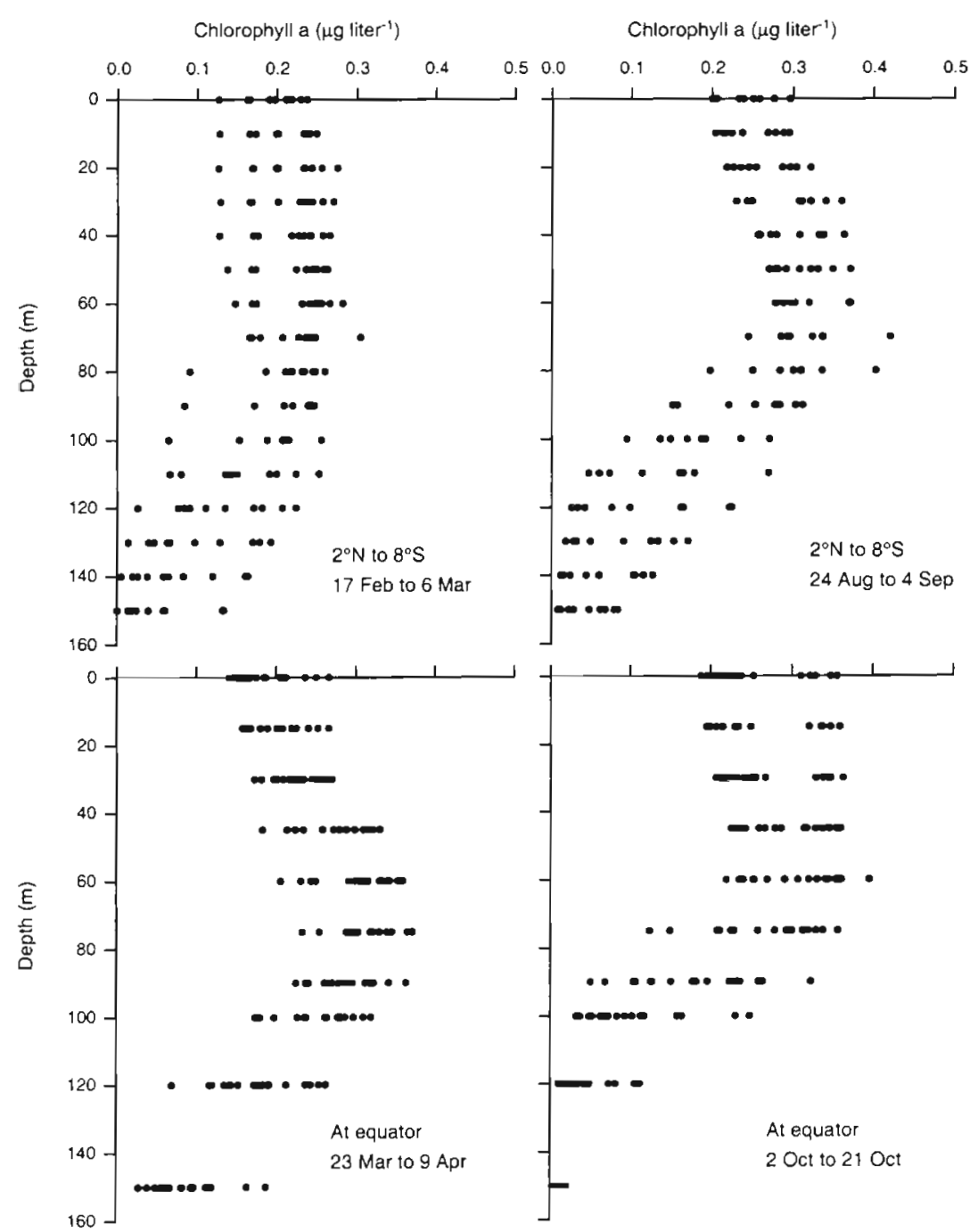

Fig. 2. Water column chlorophyll a concentrations from equatorial Pacific. February-March and August-September data (both 1992) are from $2^{\circ} \mathrm{N}$ to $8^{\circ} \mathrm{S}$ on equatorial crossings at $140^{\circ} \mathrm{W}$. March-April and October 1992 data are mostly from $0^{\circ}, 140^{\circ} \mathrm{W}$. Nitrate in this zone exceeded $4 \mu \mathrm{M}$. Chlorophyll a values are all, save one estimate of 0.512 , less than $0.5 \mathrm{\mu g} \mathrm{l}^{-1}$. Data courtesy of R. R. Bidigare

dashed lines); grazing was allowed to occur only at chlorophyll a levels exceeding $P_{0}=0.15 \mu \mathrm{g} \mathrm{chl} \mathrm{l}^{-1}$. Fasham (1995) obtained a similar result using a Holling Type III (sigmoidal) functional response (Fig. 3A,B, long-dashed lines). In operation these 2 modes of protecting the phytoplankton stock near its minimum are the same. Both model characterizations of microherbivores have 2 additional and important characteristics: (1) a basal herbivore metabolism is not included, such that when grazing stops at phytoplankton concentrations below threshold levels, no metabolic losses are incurred; and (2) microherbivores have no intrinsic mortality, apart from a predation function which serves as the model closure term (see 'Carnivory' section, be- low). Thus, when threshold phytoplankton concentrations are reached, model microherbivores enter a state of suspended animation with no metabolism and no death from starvation. All of these features parameterizing protist grazers will be shown to be problem. atic, and changing any of them produces expanding limit cycles or enhanced spring blooms in the model ecosystems in which they are embedded.

Grazing thresholds have been rationalized as energy-saving behavior, since there is no pay-off in searching for food when the energy expended in searching exceeds that gained by ingesting encountered prey. Studies with copepods do offer support for the existence of a feeding threshold (Parsons et al. 1967, 1969, Frost 1975, Frost et al. 1983, Price \& Paffenhofer 1986, Paffenhofer 1988, Wlodarczyk et al. 1992), but there is no convincing evidence for feeding thresholds in studies of protist functional responses. Though the database is not large, clearance rates of protist grazers from a range of taxa tend to increase continuously with decreasing food concentrations (Fig. 4). The few studies that appear to show pronounced feeding thresholds (Rivier et al. 1985, Eccleston-Parry \& Leadbeater 1994) did not actually measure feeding at low prey concentration. Rather, feeding thresholds were inferred from growth thresholds. If there is any maintenance metabolic cost, then growth must be zero at some low but non-zero food level, whether the grazers are trying to feed or not. A few studies do show diminution of clearance rates at low food levels, but in no case does clearance drop to low, near-zero levels. Such a drop is required by the models (Fig. $4 \mathrm{~A}$ ) to prevent reduction of phytoplankton biomass to levels far below observed minima.

Basal metabolic costs cannot be zero in organisms that search actively for food when food is hard to find. Respiration rates measured on starved protists range from 6.5 to $1800 \%$ of rates for actively growing cells, with most values falling in the 10 to $40 \%$ range (summarized by Caron et al. 1990, note that most rates appear in the older literature). For these species, which include amoebae, flagellates, and ciliates, population decreases under starvation conditions 

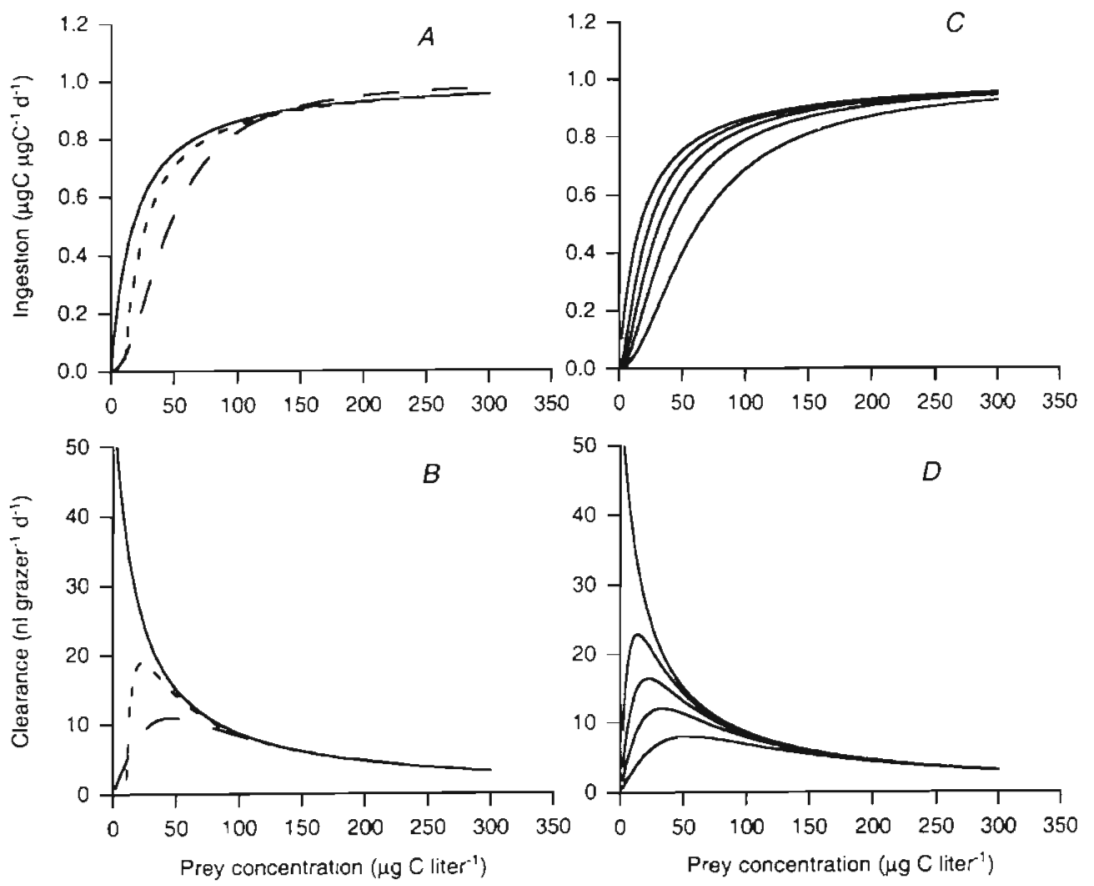

Fig. 3. (A,C) Theoretical ingestion and $(B, D)$ clearance curves for planktonic protists. (A,B) Short-dashed line represents Michaelis-Menten formulation with grazing threshold: $G=g\left(P-P_{0}\right),\left(k_{q}+P-P_{0}\right)$, where $g=1.01 \mathrm{~d}^{-1}, k_{g}=17 \mu \mathrm{g} \mathrm{Cl}^{-1}$, and $P_{0}=10 \mu \mathrm{g} \mathrm{C} \mathrm{l}^{-1}$, after Frost (1993). Solid line represents Michaelis-Menten formulation without grazing threshold $P_{0}$. Long-dashed line represents Holling type III response: $G=g \varepsilon P^{n} /\left(g+\varepsilon P^{n}\right)$, where $g=1.0 \mathrm{~d}^{-1}, \varepsilon=4.76 \times 10^{-4}\left(\mu \mathrm{g} \mathrm{Cl}^{-1}\right)^{-2}$ $\mathrm{d}^{-1}$, and $\mathrm{n}=2$, after Fasham (1995). (C,D) Suite of functional response curves for a single prey type, $P_{1}$, in the presence of a second prey type, $P_{2}$ and a grazer exhibiting switching behavior (e.g. Fasham et al. 1990): $G\left(P_{1}\right)=g j_{1} P_{1}{ }^{2} /$ $\left[k_{g}\left(j_{1} P_{1}+j_{2} P_{2}\right)+j_{1} P_{1}^{2}+j_{2} P_{2}^{2}\right]$, where $g=1.01 \mathrm{~d}^{-1}, k_{g}=17 \mu \mathrm{g} \mathrm{Cl}^{-1}$, and preference values $j_{1}$ and $j_{2}$ sum to 1 . To generate the curves, $P_{2}$ was held constant at $10 \mu \mathrm{g} C$ $\mathrm{l}^{-1}$, while $P_{1}$ ranged from 0 to $300 \mu \mathrm{g} \mathrm{Cl}^{-1}$. Preference value $j_{1}$ was varied in increments of 0.2 from 1.0 (uppermost curves) to 0.2 (lowermost curves). Note the appearance of a sigmoidal functional response (i.e. an apparent grazing threshold) in the presence of switching behavior (i.e. values of $j_{1}<1.0$ )

would be relatively rapid. Recent studies of representative pelagic taxa support this conclusion, showing mortality rates of 0.1 to $0.6 \mathrm{~d}^{-1}$ for oligotrich ciliates and heterotrophic dinoflagellates at very low or zero food levels (Strom \& Buskey 1993, Montagnes 1996, Jakobsen \& Hansen 1997). In contrast, some protist grazer species employ strategies such as gross reduction of respiration rates and/or encystment in response to starvation (Fenchel 1982, Finlay 1983). In these physiological states, protists can survive months to years without feeding. The extent to which such strategies are employed by common oceanic protist grazers is completely unknown.

The absence of both maintenance metabolic costs and starvation-induced mortality stabilizes modeled phytoplankton biomass by allowing grazer populations to persist during times of very low food availability. Based on laboratory data, however, starvation seems likely to affect a significant fraction of the grazer com- munity in microherbivore-dominated ecosystems when they approach their short-term minima in phytoplankton biomass. Thus a second key stabilizing feature of model microherbivores lack of a metabolic response to low food levels-directly conflicts with experimental evidence. Do near-zero maintenance metabolic costs actually permit microherbivore survival during periods of starvation, or are modeled zero costs a proxy for some other stabilizing mechanism?

As discussed above, there is little evidence that pelagic protistan grazers have grazing thresholds and lack significant basal metabolism. Evidence that they can resist starvation is equivocal. Putting any of these changed characterizations into the pelagic ecosystem model of Frost (1993) produces either an enhanced spring bloom or expanding limit cycles in phytoplankton stocks (Fig. 5). Similar results were obtained in experiments with the Fasham (1995) model. In particular, without a threshold corresponding roughly to actual minimal phytoplankton biomass, phytoplankton are reduced to very low levels, grazers are removed by continuing predation during the prolonged hiatus in herbivory, and phytoplankton escape grazing control when their biomass again begins to rise. With a threshold, either basal metabolism or mortality will reduce the herbivore stock when food levels are low, resulting in a spring phytoplankton accumulation and fall nitrate draw-down in excess of that actually observed (Fig. 5).

Apparently we do not yet possess the full explanation of phytoplankton biomass control in HNLC pelagic ecosystems. This general issue-the means by which consumers avoid exterminating their prey-is a long-standing problem in ecology, and candidate explanations must now be sought for HNLC systems in particular. In addition to grazing thresholds, possible explanations include spatial and temporal inhomogeneity (patchiness) in the habitat, control of grazers by their predators (carnivory), and switching to alternative prey. Below we examine these possibilities and conclude that, while biomass control on the level of phytoplankton-micrograzer interactions is the most likely, none can be eliminated either by logic alone or by present information for the case of phytoplankton biomass minima in HNLC ecosystems. 

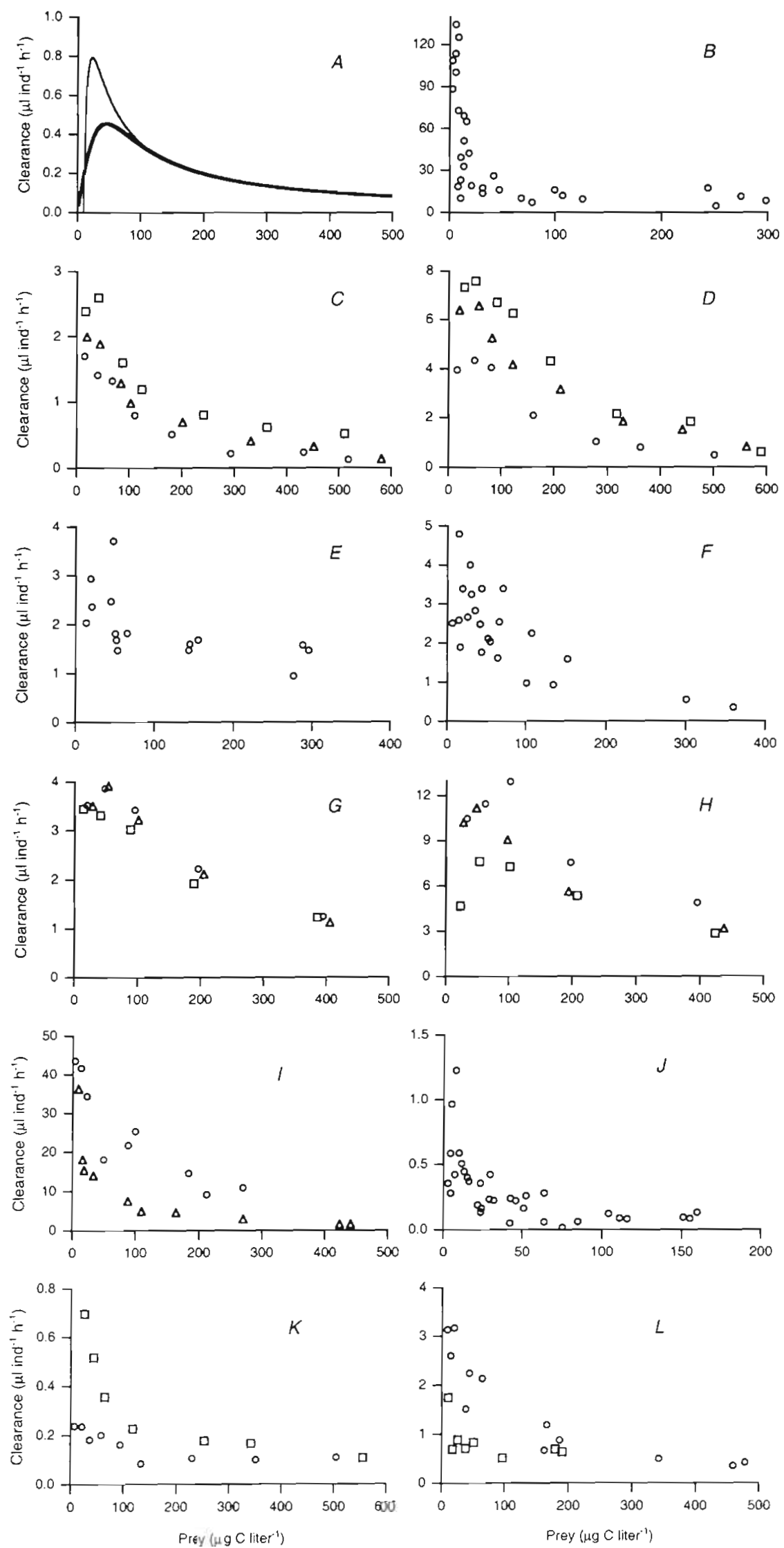

Fig. 4. Clearance rates ( $\mu l$ ind $^{-1} \mathrm{~h}^{-1}$ ) as a function of algal prey concentration: $(A)$ as predicted by subarctic plankton dynamics model formulation (thin line: Frost 1993; thick line: Fasham 1995; (B-L) as measured during laboratory experiments with planktonic protist grazers. Data were obtained from published graphs using NIH Image 1.44 software. For cases in which prey concentrations were reported as cells $\mathrm{ml}^{-1}$ and prey cell $C$ content was not stated, conversion to $C$ concentration used reported prey cell dimensions and the 'constrained' factor of $183 \mathrm{fg} \mathrm{C} \mathrm{mm}^{-3}$ (Caron et al. 1995). (B) Favella sp. fed Heterocapsa triquetra (Buskey \& Stoecker 1988); (C) Tintinnopsis acuminata fed Isochrysis galbana; (D) Tintinnopsis vasculum fed Dicratenia inornata. Both from Verity (1985); symbols represent different experimental temperatures. (E) T. cf. acuminata fed a mixture of $I$. galbana and Monochrysis lutheri; (F) Helicostomella subulata fed I. galbana. Both from Heinbokel (1978). (G) Strobilidium of. spiralis and (H) Tintinnopsis dadayi; symbols represent diets of different plastidic and aplastidic flagellate species. Both from Verity (1991b). (I) Paraphysomonas vestita spp. vestita fed Nitzschia palea $(\Delta)$ and Nitzschia acicularis (O) (Grover 1990). (J) Gymnodinium sp. fed I. galbana (Strom 1991). (K) Oblea rotunda fed Ditylum brightwellii $(\square)$ and Dunaluella tertiolecta (o) (Strom \& Buskey 1993). (L) Gyrodinium dominans fed $H$. triquetra; symbols represent 2 different $G$. dominans strains

(Nakamura et al. 1995) 


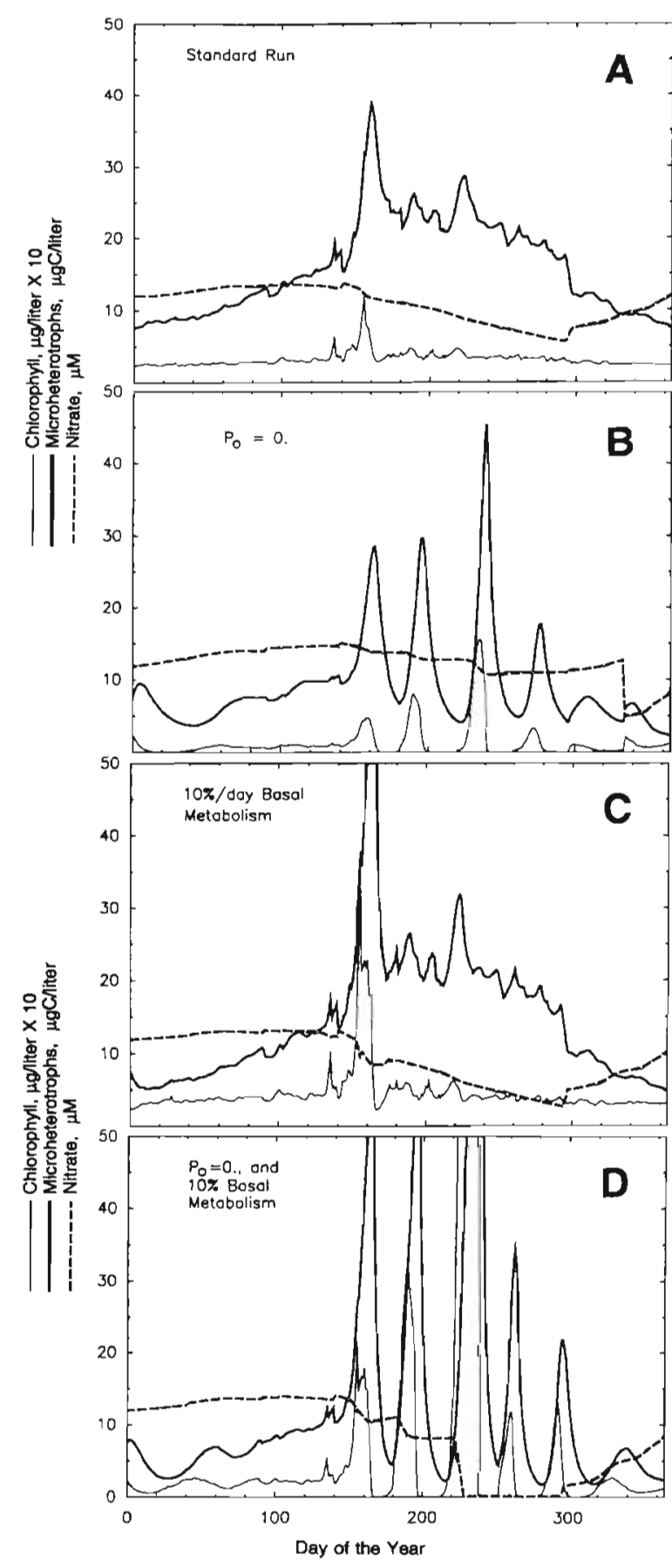

Fig. 5. Effects of changes to Frost's (1993) model of subarctic Pacific ecosystem relationships. (A) Standard run. Thin lines: chlorophyll a $\left(\mu \mathrm{g}^{-1} \times 10\right)$; thick lines: microherbivores $(\mu \mathrm{g} \mathrm{C}$ $\left.\mathrm{I}^{-1}\right)$; dashed lines: nitrate $(\mu \mathrm{M})$. (B) Grazing threshold, $P_{0}$, set to zero. Peaks in chlorophyll are not beyond limits reached occasionally (Miller et al. 1991), but decreases to near-zero chlorophyll are not observed. (C) Basal metabolism of $10 \%$ $\mathrm{d}^{-1}$ added for microheterotrophs. This installs a modest spring bloom. (D) $P_{0}=0$ and $10 \% \mathrm{~d}^{-1}$ microheterotroph respiration. Model destabilizes with repeated depletion of phytoplankton and all nitrate consumed by Day 230. Qualitatively identical results are obtained when modest rates of microherbivore mortality (at $P \leq P_{0}$ ) are incorporated into the standard run
HNLC plankton dynamics models predict phytoplankton thresholds of ca $10 \mu \mathrm{g} \mathrm{Cl}^{-1}$, equivalent to observed biomass minima. Most laboratory studies have also used relatively large protist grazer and phytoplankton prey species, while phytoplankton $\leq 5 \mu \mathrm{m}$ and correspondingly small $(\leq 20 \mu \mathrm{m})$ protist grazers dominate HNLC waters (Booth et al. 1993, Vors et al. 1995, Chavez et al. 1996).

A related issue is the use of isolates that have been in culture for many (often $>100$ ) generations. Grazing behavior of protists is known to be labile (Choi 1994), and adaptation to laboratory conditions (maintenance diets restricted in composition, unrealistically high and fluctuating food levels) over many generations may produce 'unnatural' behavioral responses (Montagnes et al. 1996). Thus, these organisms may not be representative of naturally occurring, oceanic protists, which could retain grazing thresholds in the field. Lessard \& Murrell (1998) present evidence from field experiments that Sargasso Sea microzooplankton communities may exhibit grazing thresholds corresponding to minimal observed phytoplankton concentrations in that region. Clearly, further work on natural grazer assemblages and representative oceanic protist species is needed to resolve key behavioral responses to very low prey abundance.

\section{PATCHINESS}

Inclusion of 1 or more spatial dimensions in plankton dynamics models can generate patchy distributions which, through diffusional exchange, permit persistence of prey populations that might otherwise be driven to extinction by their predators (Okubo 1980, DeAngelis 1992). This effect was claimed for the model of Wroblewski \& O'Brien (1976) and can be inferred for the models of Steele \& Mullin (1977) and Hofmann (1988). Indeed, Walsh (1975) interpreted the grazer feeding threshold in plankton models as simply a parameterization of patchiness and its effects, even in spatial models. He postulated that the maintenance of low phytoplankton biomass and high nutrient levels in oceanic divergences was due to close coupling between phytoplankton production and zooplankton grazing, promoted by the low short-term physical variance of these systems (Walsh 1976). It is important to recognize, however, that stabilization of the phytoplankton-grazer system and regulation of absolute phytoplankton abundance are 2 different things. We are unaware of examples in which inclusion of spatial structure in a model obviated the need for a stabilizing grazer functional response when simulation of $o b$ served phytoplankton abundances was sought. For example, Wroblewski \& O'Brien (1976) concluded from 
their spatial model that diffusion of phytoplankton cells from areas of high to low concentration prevented the local extinction of phytoplankton; both spatial and non-spatial version of the model were insensitive to grazer feeding thresholds. However, although the model used parameter values chosen as relevant to Ocean Station P in the open subarctic Pacific, it produced a high-chlorophyll low-nitrate steady-state condition, not the observed HNLC condition. With appropriate increase in the grazing parameter $(\Lambda)$, it can be shown that Wroblewski \& $O^{\prime}$ Brien's non-spatial model will produce an HNLC condition that, in this modified version, is highly dependent on a positive grazer feeding threshold. It remains to be determined how this change would affect the sensitivity of the plankton dynamics in the spatial version of Wroblewski \& O'Brien's model, but we think it will have a significant effect on the predicted phytoplankton concentration: without some sort of threshold grazing response the simulated phytoplankton concentration may be very much lower than observed. We draw this conclusion from consideration of the biological characteristics of the major grazers in HNLC regions.

Models of plankton dynamics with spatial structure have typically parameterized the major grazers as copepods. Owing to the long generation times of copepods, their population increases are readily uncoupled from phytoplankton production events by physical disturbance; the results of Hofmann (1988) are relevant. However, the same is not true for protist grazers, whose population growth rates may exceed those of phytoplankton (summarized by Hansen et al. 1997). Furthermore, protist grazers may be similar in size and behavior to their phytoplankton prey (e.g. photosynthetic vs heterotrophic dinoflagellates), and in the case of mixotrophy, now known to be widespread, photosynthetic ability and ingestion of phytoplankton can be embodied in the same individual. Given this considerable overlap, and the smoothing effect of turbulent diffusion acting in a similar fashion and rate on both phytoplankton and their protist grazers, it is difficult to envision a physical sorting mechanism operable in either time or space that would allow substantial, persistent uncoupling of phytoplankton and their micrograzers. The observed lower limits of phytoplankton concentration in HNLC areas are unlikely to be sustained solely by spatial heterogeneity persisting in the presence of turbulent diffusion.

On sub-Kolmogorov scales, it is possible that spatial 'refuges' might be created by small-scale patchiness due to gels, transparent exopolymeric substances (TEP), and the like (Alldredge et al. 1993, Chin et al. 1998). Either behavioral (chemosensory, motility) responses to such patches or enhanced growth rates in the patch environment could create a heterogeneous distribution of microbial organisms. The notion that small-scale structures profoundly influence interactions between planktonic microbes has been discussed at length in the literature (Shanks \& Trent 1979, Azam \& Ammerman 1984, Goldman 1988, Azam et al. 1994). As with turbulent diffusion, however, small-scale patchiness can only provide a refuge from grazers (and hence determine lower limits of phytoplankton biomass) if phytoplankton and grazers respond differently to, and can thus be uncoupled by, the patch environment.

\section{CARNIVORY}

Control of grazer populations by higher trophic level predators (carnivory) has been proposed as a mechanism to provide ecosystem stability in the absence of feeding thresholds (Landry 1976). This analysis was extended by Steele \& Henderson (1992), who demonstrated that, though carnivory could stabilize biomass levels, a temporally stable planktonic ecosystem with high-nutrient and low-phytoplankton levels could be maintained only in the presence of feeding thresholds (in their model, a sigmoidal functional response). Conversely, depending on the choice of predation parameters, unstable behavior can result even from models incorporating Holling type III or other forms of densitydependent carnivorous control of herbivores (Steele \& Henderson 1992, Caswell \& Neubert 1998). This indicates that top-down regulation of herbivores is a necessary but not sufficient condition for control of both minimum and maximum phytoplankton biomass in HNLC systems (Steele 1974).

In general, there are at least 2 reasons why predation control is not as compelling as phytoplanktonherbivore interaction as a locus for phytoplankton biomass stabilization. First, predation control requires continuous predation. At some level, predation in planktonic ecosystems will be vested in metazoa, whether they feed directly on herbivorous protists or on individuals (e.g. carnivorous protists) occupying higher trophic niches. The complex life history patterns and, in higher latitude systems such as the subarctic Pacific, the non-feeding overwintering behaviors of these organisms make them unlikely to meet the criteria of continuous presence and activity. Second, ecosystem dynamics models are highly sensitive to predation parameter values. Only a fairly narrow range of values will result in model output that reflects field observations. This means that, in the absence of other processes regulating phytoplankton biomass, HNLC systems would be not at all robust to changes in the identity and capabilities of carnivores. Long-term observation of oceanic ecosystems such as the subarctic Pacific suggests that the mechanisms promoting sta- 
bility do not fail. Grazing of phytoplankton biomass to levels low enough to initiate limit cycles does not occur. Thus we believe that phytoplankton-herbivore interactions must be key to behavioral stabilization mechanisms.

\section{MULTIPLE-PREY AND MULTIPLE-PREDATOR DYNAMICS}

Switching behavior by predators, that is, disproportionate grazing on the more abundant of multiple prey types, has been postulated to exert a stabilizing influence on prey biomass (Murdoch 1969, Oaten \& Murdoch 1975, Hutson 1984). A switching function (Fig. 3C,D) was able to replace the feeding threshold in the North Atlantic model of Fasham et al. (1990), though it should be noted that phytoplankton mortality, and not grazing, was the primary fate of phytoplankton in that model system (Haney \& Jackson 1996). For copepods, there is a growing body of evidence that switching can occur (Gismervik \& Andersen 1997, and references therein). For planktonic protist grazers, rigorous studies have not been done. Disproportionate grazing on more abundant prey, suggestive of switching behavior, has been observed in some laboratory experiments (Goldman \& Dennett 1990, Strom 1991), though not in others (Verity 1991b). The effect of switching behavior is to produce a sigmoidal or Holling type III functional response for the individual prey types in the mixture (Fig. 3C,D). This suggests that a possible explanation for the lack of observed feeding thresholds in the laboratory stems from the extensive use of single prey experiments. Apparent feeding thresholds may arise from selective feeding behavior when feeding on the most abundant prey is disproportionate. Prey types at low abundance would then experience a refuge even though total feeding activity by the grazer was not reduced. Under conditions (such as laboratory experiments) with only 1 prey type available the refuge, or threshold, would never appear. In HNLC systems, micrograzers might switch among multiple phytoplankton taxa, or between phytoplankton and other particle types such as bacteria or detritus.

Absolute abundance of prey has also been hypothesized to influence prey selection when multiple prey types are available (Stephens \& Krebs 1986). Under the simplest (i.e. energy-based) formulations of foraging theory, selection should occur only at high prey concentrations, when ingestion of suboptimal prey would interfere with maximum energy gain (Lehman 1976, Stephens \& Krebs 1986). However, the need for nutrients that may be embodied only in specific prey types, or limited tolerance for deleterious compounds in the prey, may lead to selection that persists down to very low food levels. Strom \& Loukos (1998) have shown that such persistence is a prerequisite for abundancebased selection to stabilize predator-prey systems. Experimental evidence for selection behavior related to prey abundance can be seen in the nanoflagellate grazing data of Jürgens \& DeMott (1995), as well as the tintinnid grazing data of Heinbokel (1978). Whether switching or abundance-based selection is the specific mechanism, behavioral flexibility is the key to selective feeding as a stabilization mechanism. Almost nothing is known, however, about how protist selection behavior changes in response to prey availability.

Omnivory on the part of microheterotrophs - that is, the ability to consume one another as well as phytoplankton -is a special case of selective feeding behavior that can have a profoundly stabilizing effect on plankton biomass cycles. If micrograzers switch to feeding on one another when phytoplankton prey become scarce, not only is grazing pressure on phytoplankton relieved, but the biomass of potential consumers is likewise reduced. Preliminary model experiments (unpubl. data) show that a non-linear 'omnivory' function, in which micrograzer preference for each other increases exponentially with decreasing phytoplankton abundance, can reproduce both the broad constancy and small-scale fluctuations observed in subarctic Pacific chlorophyll biomass (Fig. 1B) without the requirement of a grazing threshold. Because modeled micrograzers represent a naturally occurring community of mixed species, such omnivory need not actually represent one individual consuming another of the same species (i.e. cannibalism). While almost nothing is known about the prevalence of micrograzer omnivory, a limited set of laboratory and field observations (e.g. Dolan \& Coats 1991a,b, Verity 1991a, Jacobson \& Anderson 1996) confirms that omnivorous feeding by planktonic protists is indeed possible.

Just as laboratory studies typically involve only 1 prey type at a time, they also tend to focus on grazer species in isolation from one another. In nature, of course, numerous grazer types co-exist. Behavioral shifts in models may represent natural successional changes in grazer species composition, with 'guilds' of grazers replacing one another over time and bringing various behaviors to the system. In other words, even if a modeled range of behavior is not observed in studies of a single grazer taxon, it may be justifiable if supported by the grazer community as a whole. This explanation has been proffered by Fasham et al. (1990) to justify the use of a switching response on the part of the herbivores in their model. Explicit evaluation of this metapopulation approach is needed. If the models do in fact represent changing grazer communities, it should be possible to (1) obtain the 'required' meta- 
population functional responses by combining known responses of individual species, and (2) observe a changing grazer community in nature that corresponds to that demanded by the model behavioral 'requirements'

\section{SYNTHESIS}

Better description of stabilizing mechanisms in plankton dynamics models is not a useful exercise unless such mechanisms have a significant effect on the predictive power of the models. We believe that they do. For example, suppose that stability of modeled plankton 'populations' is vested in spatial patchiness. Climactic changes that have been observed over the subarctic North Pacific in recent decades, including increased wind stress and increased stratification (Polovina et al. 1995), might well affect spatial patchiness by altering turbulent mixing rates. A model stabilized by patchiness would predict large changes in phytoplankton biomass and its variability under this altered regime. Alternatively, in a system stabilized by carnivory, the observed shift to an earlier life cycle on the part of Neocalanus plumchrus (Mackas et al. 1998), a principal predator of subarctic microzooplankton, should influence the stability of the microherbivorephytoplankton link during the critical spring period.

Although our analysis has focused on HNLC regions, the issue of lower phytoplankton biomass limits is, of course, germane to other ocean provinces. In the great subtropical gyres, both minimum and average chlorophyll concentrations are lower than in HNLC waters (e.g. Venrick 1993, Caron et al. 1995). Higher irradiances and lower nutrient availability in subtropical waters should promote higher carbon:chlorophyll ratios there (Geider 1987, Geider et al. 1997), so that some portion of the biomass discrepancy may be only apparent. There are very few data on either carbon:chlorophyll ratios or carbon-based biomass estimates for subtropical phytoplankton communities. On the other hand, subtropical phytoplankton communities are typically dominated by even smaller cells (prokaryotes, $\leq 2 \mu \mathrm{m}$ eukaryotes) than those of HNLC waters (Goericke \& Welschmeyer 1993, Campbell et al. 1994), probably leading to fundamental shifts in the identity of the dominant protist 'herbivores' (e.g. $5 \mu \mathrm{m}$ flagellates vs 10 to $20 \mu \mathrm{m}$ dinoflagellates and ciliates). Could such contrasts in community structure be linked to different grazing behaviors and capabilities at very low prey abundances?

The mismatch between model formulation and empiricism, as discussed in this paper, means that our understanding of the large HNLC ecosystems is fundamentally incomplete. The question 'What sets lower limits of phytoplankton biomass in HNLC regions? appears to have its locus in the fundamental biology of oceanic microherbivores, primarily protists. An experimental focus on the physiological and behavioral capabilities of representative microherbivores will be required to make progress in this area. This progress will be enhanced if experimentation is explicitly coupled with model investigations on both the population and HNLC community level. Taking the larger view, our ability to predict the responses of the ocean to change rests on models such as those described here. The utility of such models as tools depends entirely on the degree to which they realistically encapsulate biology; that is, they must incorporate biological truth about the key species in the ecosystem (Verity \& Smetacek 1996). Our analysis suggests that hypothesis-driven oceanographic investigation of a key species complexprotist micrograzers - could yield large advances in our understanding of how HNLC biomass limits are maintained.

Acknowledgements. We thank N. Welschmeyer and R. Bidigare for providing subarctic and equatorial Pacific chlorophyll data, respectively. K. Bright assisted with preparation of Fig. 4. The paper was improved by comments from J. Cullen and an anonymous reviewer. Support for this work was provided by NSF and NOAA (OCE-9301698 and OCE-9711273 to S.L.S.). This is contribution number 117 of the US GLOBEC program, funded jointly by NSF and NOAA.

\section{LITERATURE CITED}

Alldredge AL, Passow U, Logan BE (1993) The abundance and significance of a class of large, transparent organic particles in the ocean. Deep-Sea Res 40:1131-1140

Azam F, Ammerman JW (1984) Mechanisms of organic matter utilization by marine bacterioplankton. In: Holm-Hansen O, Bolis L, Gilles R (eds) Marine phytoplankton and productivity. Springer-Verlag, Berlin, p 45-54

Azam F, Smith DC, Steward GF, Hagström \& (1994) Bacteriaorganic matter coupling and its significance for ocean carbon cycling. Microb Ecol 28:167-179

Banse K (1992) Grazing, temporal changes of phytoplankton concentrations, and the microbial loop in the open sea. In: Falkowski PG, Woodhead AD (eds) Primary productivity and biogeochemical cycles in the sea. Plenum, New York, p 409-440

Booth BC, Lewin J, Postel JR (1993) Temporal variation in the structure of autotrophic and heterotrophic communities in the subarctic Pacific. Prog Oceanogr 32:57-99

Buskey EJ, Stoecker DK (1988) Locomotory patterns of the planktonic ciliate Favella sp.: adaptations for remaining within food patches. Bull Mar Sci 43:783-796

Campbell L, Nolla HA, Vaulot D (1994) The importance of Prochlorococcus to community structure in the central North Pacific Ocean. Limnol Oceanogr 39:954-961

Caron DA, Goldman JC, Fenchel T (1990) Protozoan respiration and metabolism. In: Capriulo GM (ed) Ecology of marine protozoa. Oxford University Press, New York, p $307-322$

Caron DA, Dam HG, Kremer P, Lessard EJ, Madin LP, Malone 
TC, Napp JM, Peele ER, Roman MR, Youngbluth MJ (1995) The contribution of microorganisms to particulate carbon and nitrogen in surface waters of the Sargasso Sea near Bermuda. Deep-Sea Res I 42:943-972

Caswell H, Neubert MG (1998) Chaos and closure terms in plankton food chain models. J Plankton Res 20:1837-1845

Chavez FP, Buck KR, Service SK, Newton J, Barber RT (1996) Phytoplankton variability in the central and eastern tropical Pacific. Deep-Sea Res II 43:835-870

Chin WC, Orellana MV, Verdugo P (1998) Spontaneous assembly of marine dissolved organic matter into polymer gels. Nature 391:568-572

Chisholm SW, Morel FMM (1991) Preface to symposium volume: What controls phytoplankton production in nutrientrich areas of the open sea? Limnol Oceanogr 36

Choi JW (1994) The dynamic nature of protistan ingestion response to prey abundance. J Eukaryot Microbiol 41 $137-146$

Coale KH and 18 others (1996) A massive phytoplankton bloom induced by an ecosystem-scale iron fertilization experiment in the equatorial Pacific Ocean. Nature 383:495-501

Cullen JJ (1991) Hypotheses to explain high-nutrient conditions in the open sea. Limnol Oceanogr 36:1578-1599

DeAngelis DL (1992) Dynamics of nutrient cycling and food webs. Chapman and Hall, London

Dolan JR, Coats DW (1991a) Preliminary prey digestion in a predacious estuarine ciliate, and the use of digestion data to estimate ingestion. Limnol Oceanogr 36:558-565

Dolan JR, Coats DW (1991b) A study of feeding in predacious ciliates using prey ciliates labeled with fluorescent microspheres. J Plankton Res 13:609-627

Eccleston-Parry JD, Leadbeater BSC (1994) A comparison of the growth kinetics of six marine heterotrophic nanoflagellates fed with one bacterial species. Mar Ecol Prog Ser 105:167-177

Fasham MJR (1995) Variations in the seasonal cycle of biological production in subarctic oceans: a model sensitivity analysis. Deep-Sea Res 42:1111-1149

Fasham MJR, Ducklow HW, McKelvie SM (1990) A nitrogenbased model of plankton dynamics in the oceanic mixed layer. J Mar Res 48:591-639

Fenchel T (1982) Ecology of heterotrophic microflagellates. III. Adaptations to heterogeneous environments. Mar Ecol Prog Ser 9:25-33

Finlay BJ (1983) Influence of physiological state on indices of respiration rate in protozoa. Comp Biochem Physiol 74A: 211-219

Franks PJS, Wroblewski JS, Flierl GR (1986) Behavior of a simple plankton model with food-level acclimation by herbivores. Mar Biol 91:121-129

Froneman PW, Perissinotto R (1996) Structure and grazing of the microzooplankton communities of the subtropical convergence and a warm-core eddy in the Atlantic sector of the Southern Ocean. Mar Ecol Prog Ser 135:237-245

Frost BW (1975) A threshold feeding behavior in Calanus pacificus. Limnol Oceanogr 20:263-266

Frost BW (1991) The role of grazing in nutrient-rich areas of the open sea. Limnol Oceanogr 36:1616-1630

Frost BW (1993) A modelling study of processes regulating plankton standing stock and production in the open subarctic Pacific Ocean. Prog Oceanogr 32:17-56

Frost BW, Franzen NC (1992) Grazing and iron limitation in the control of phytoplankton stock and nutrient concentration: a chemostat analogue of the Pacific equatorial upwelling zone. Mar Ecol Prog Ser 83:291-303

Frost BW, Landry MR, Hassett RP (1983) Feeding behavior of large calanoid copepods Neocalanus cristatus and $N$. plumchrus from the subarctic Pacific Ocean. Deep-Sea Res 30:1-13

Geider RJ (1987) Light and temperature dependence of the carbon to chlorophyll a ratio in microalgae and cyanobacteria: implications for physiology and growth of phytoplankton. New Phytol 106:1-34

Geider RJ, MacIntyre HL, Kana TM (1997) A dynamic model of phytoplankton growth and acclimation: responses of the balanced growth rate and the chlorophyll a:carbon ratio to light, nutrient-limitation and temperature. Mar Ecol Prog Ser 148:187-200

Gismervik I, Andersen T (1997) Prey switching by Acartia clausi: experimental evidence and implications of intraguild predation assessed by a model. Mar Ecol Prog Ser $157: 247-259$

Goericke R, Welschmeyer NA (1993) The marine prochlorophyte Prochlorococcus contributes significantly to phytoplankton biomass and primary production in the Sargasso Sea. Deep-Sea Res 40:2283-2294

Goldman JC (1988) Spatial and temporal discontinuities of biological processes in pelagic surface waters. In: Rothschild BJ (ed) Toward a theory on biological-physical interactions in the world ocean. Kluwer Academic Publishers, Dordrecht, p 273-296

Goldman JC, Dennett MR (1990) Dynamics of prey selection by an omnivorous flagellate. Mar Ecol Prog Ser 59:183-194

Grover JP (1990) Grazing by a heterotrophic microflagellate on two diatoms: functional and numerical responses in laboratory cultures. Arch Hydrobiol 119:197-214

Haney JD, Jackson GA (1996) Modeling phytoplankton growth rates. J Plankton Res 18:63-85

Hansen PJ, Bjornsen PK, Hansen BW (1997) Zooplankton grazing and growth: scaling within the $2-2000 \mu \mathrm{m}$ body size range. Limnol Oceanogr 42:687-704

Heinbokel JF (1978) Studies on the functional role of tintinnids in the Southern California Bight. I. Grazing and growth rates in laboratory cultures. Mar Biol 47:177-189

Hofmann EE (1988) Plankton dynamics on the outer southeastern U.S. continental shelf. Part III: A coupled physicalbiological model. J Mar Res 46:919-946

Hutson V (1984) Predator mediated coexistence with a switching predator. Math Biosci 68:233-246

Jacobson DM, Anderson DM (1993) Growth and grazing rates of Protoperidinium hirobis Abe, a thecate heterotrophic dinoflagellate. J Plankton Res 15:723-726

Jacobson DM, Anderson DM (1996) Widespread phagocytosis of ciliates and other protists by marine mixotrophic and heterotrophic thecate dinoflagellates. J Phycol 32:279-285

Jakobsen HH, Hansen PJ (1997) Prey size selection, grazing and growth response of the small heterotrophic dinoflagellate Gymnodinium sp. and the ciliate Balanion comatum-a comparative study. Mar Ecol Prog Ser 158:75-86

Jeong HJ, Latz MI (1994) Growth and grazing rates of the heterotrophic dinoflagellates Protoperidinium spp. on red tide dinoflagellates. Mar Ecol Prog Ser 106:173-185

Jürgens K, DeMott WR (1995) Behavioral flexibility in prey selection by bacterivorous nanoflagellates. Limnol Oceanogr 40:1503-1507

Kamiyama T, Arima S (1997) Lethal effect of the dinoflagellate Heterocapsa circularisquama upon the tintinnid ciliate Favella taraikaensis. Mar Ecol Prog Ser 160:27-33

Landry MR (1976) The structure of marine ecosystems: an alternative. Mar Biol 35:1-7

Landry MR, Monger BC, Selph KE (1993) Time-dependency of microzooplankton grazing and phytoplankton growth in the subarctic Pacific. Prog Oceanogr 32:205-222

Landry MR, Constantinou J, Kirshtein J (1995) Microzoo- 
plankton grazing in the central equatorial Pacific during February and August, 1992. Deep-Sea Res II 42:657-671

Landry MR, Barber RT, Bidigare R, Chai F, Coale KH, Dam HG, Lewis MR, Lindley ST, McCarthy JJ, Roman MR, Stoecker DK, Verity PG. White JR (1997) Iron and grazing constraints on primary production in the central equatorial Pacific: an EqPac synthesis. Limnol Oceanogr 42:405-418

Lehman JT (1976) The filter-feeder as an optimal forager, and the predicted shapes of feeding curves. Limnol Oceanogr 21:501-516

Lessard EJ, Murrell MC (1998) Microzooplankton herbivory and phytoplankton growth in the northwestern Sargasso Sea. Aquat Microb Ecol 16:173-188

Lochte K, Ducklow HW, Fasham MJR, Stienen C (1993) Plankton succession and carbon cycling at $47^{\circ} \mathrm{N}, 20^{\circ} \mathrm{W}$ during the JGOFS North Atlantic Bloom Experiment. Deep-Sea Res II 40:91-114

Mackas DL, Goldblatt R, Lewis AG (1998) Interdecadal variation in developmental timing of Neocalanus plumchrus populations at Ocean Station $\mathrm{P}$ in the subarctic North Pacific. Can J Fish Aquat Sci 55:1878-1893

Martin JH, Gordon RM, Fitzwater S, Broenkow WW (1989) VERTEX: phytoplankton/iron studies in the Gulf of Alaska. Deep-Sea Res 36:649-680

Martin JH and 43 others (1994) Testing the iron hypothesis in ecosystems of the equatorial Pacific Ocean. Nature 371: $123-129$

McAllister CD (1962) Data record, photosynthesis and chlorophyll a measurements at Ocean Weather Station 'P', July 1959 to November 1961 Fish Res Board Can Manuscript Rep Ser (Oceanogr Limnol) 126

McAllister CD, Parsons TR, Strickland JDH (1959) Data record, oceanic fertility and productivity measurements at Ocean Weather Station ' $P$ ', July and August 1959. Fish Res Board Can Manuscript Rep Ser (Oceanogr Limnol) 55

Miller CB (1993) Pelagic production processes in the Subarctic Pacific. Prog Oceanogr 32:1-15

Miller CB, Frost BW, Wheeler PA, Landry MR, Welschmeyer $N$, Powell TM (1991) Ecological dynamics in the subarctic Pacific, a possibly iron-limited ecosystem. Limnol Oceanogr $36: 1600-1615$

Moloney CL, Field JG (1991) The size-based dynamics of plankton food webs. I. A simulation model of carbon and nitrogen flows. J Plankton Res 13:1003-1038

Montagnes DJS (1996) Growth responses of planktonic ciliates in the genera Strobilidium and Strombidium. Mar Ecol Prog Ser 130:241-254

Montagnes DJS, Berger JD, Taylor FJR (1996) Growth rate of the marine planktonic ciliate Strombidinopsis cheshiri Snyder and Ohman as a function of food concentration and interclonal variability. J Exp Mar Biol Ecol 206: $121-132$

Morel FMM, Rueter JG. Price NM (1991) Iron nutrition of phytoplankton and its possible importance in the ecology of ocean regions with high nutrient and low biomass. Oceanography 4:56-61

Murdoch WW (1969) Switching in general predators: experiments on predator specificity and stability of prey populations. Ecol Monogr 39:335-354

Murray JW, Barber RT, Roman MR, Bacon MP, Feely RA (1994) Physical and biological controls on carbon cycling in the equatorial Pacific. Science 266:58-65

Nakamura Y, Suzuki S, Hiromi J (1995) Growth and grazing of a naked heterotrophic dinoflagellate, Gyrodinium dominans. Aquat Microb Ecol 9:157-164

Oaten A, Murdoch WW (1975) Functional response and stability in predator-prey systems. Am Nat 109:289-298
Okubo A (1980) Diffusion and ecological problems: mathematical models. Springer-Verlag, Berlin

Paffenhofer GA (1988) Feeding rates and behavior of zooplankton. Bull Mar Sci 43:430-445

Parsons TR, LeBrasseur RJ, Fulton JD (1967) Some observations on the dependence of zooplankton grazing on the cell size and concentration of phytoplankton blooms. J Oceanogr Soc Jpn 23:10-17

Parsons TR, LeBresseur RJ, Fulton JD, Kennedy OD (1969) Production studies in the Strait of Georgia. II. Secondary production under the Fraser River plume, February to May, 1967. J Exp Mar Biol Ecol 3:39-50

Polovina JJ, Mitchum GT, Evans GT (1995) Decadal and basin-scale variation in the mixed layer depth and the impact on biological production in the Central and North Pacific, 1960-88. Deep-Sea Res 42:1701-1716

Price HJ, Paffenhofer G (1986) Effects of concentration on the feeding of a marine copepod in algal monocultures and mixtures. J Plankton Res 8:119-128

Price NM, Ahner BA, Morel FMM, Parsons RM (1994) The equatorial Pacific Ocean: grazer-controlled phytoplankton populations in an iron-limited system. Limnol Oceanogr 39:520-534

Rivier A, Brownlee DC, Sheldon RW, Rassoulzadegan F (1985) Growth of microzooplankton: a comparative study of bacterivorous zooflagellates and ciliates. Mar Microb Food Webs 1:51-60

Shanks AL, Trent JD (1979) Marine snow: microscale nutrients patches. Limnol Oceanogr 24:850-854

Sherr EB, Sherr BF (1994) Bacterivory and herbivory: key roles of phagotrophic protists in pelagic food webs. Microb Ecol 28:223-235

Steele JH (1974) The structure of marine ecosystems. Harvard University Press, Cambridge

Steele JH, Henderson EW (1992) The role of predation in plankton models. J Plankton Res 14:157-172

Steele JH, Mullin MM (1977) Zooplankton dynamics. In: Goldberg ED (ed) The sea. Wiley, New York, p 857-890

Stephens DW, Krebs JR (1986) Foraging theory. Princeton University Press, Princeton

Stephens K (1964) Data record, productivity measurements in the Northeast Pacific with associated chemical and physical data, 1958-1964. Fish Res Board Can Manuscript Rep Ser (Oceanogr Limnol) 179

Stephens K (1966) Data record. Primary production data from the Northeast Pacific, January 1964 to December 1965. Fish Res Board Can Manuscript Rep Ser (Oceanogr Limnol) 209

Stephens K (1968) Data record. Primary production data from the Northeast Pacific, January 1966 to December 1967. Fish Res Board Can Manuscript Rep Ser (Oceanogr Limnol) 957

Stephens K (1977) Primary production data from weatherships occupying Ocean Station 'P' 1969 to 1975. Fish Mar Serv Data Rep 38

Strom SL (1991) Growth and grazing rates of the herbivorous dinoflagellate Gymnodinium sp. from the open subarctic Pacific Ocean. Mar Ecol Prog Ser 78:103-113

Strom SL, Buskey EJ (1993) Feeding, growth, and behavior of the thecate heterotrophic dinoflagellate Oblea rotunda. Limnol Oceanogr 38:965-977

Strom SL, Loukos H (1998) Selective feeding by protozod: model and experimental behaviors and their consequences for population stability. J Plankton Res 20:831-846

Strom SL, Welschmeyer NA (1991) Pigment-specific rates of phytoplankton growth and microzooplankton grazing in the open subarctic Pacific Ocean. Limnol Oceanogr 36:50-63 
Venrick EL (1993) Phytoplankton seasonality in the North Pacific: the endless summer reconsidered. Limnol Oceanogr 38:1135-1149

Verity PG (1985) Grazing, respiration, excretion, and growth rates of tintinnids. Limnol Oceanogr 30:1268-1282

Verity PG (1991a) Feeding in planktonic protozoans: evidence for non-random acquisition of prey. J Protozool 38 : $69-76$

Verity PG (1991b) Measurement and simulation of prey uptake by marine planktonic ciliates fed plastidic and aplastidic nanoplankton. Limnol Oceanogr 36:729-750

Verity PG, Smetacek V (1996) Organism life cycles, predation, and the structure of marine pelagic ecosystems. Mar Ecol Prog Ser 130:277-293

Verity PG, Stoecker DK, Sieracki ME, Nelson JR (1993) Grazing, growth and mortality of microzooplankton during the

Editorial responsibility: Michael Landry (Contributing Editor), Honolulu, Hawaii, USA
1989 North Atlantic spring bloom at $47^{\circ} \mathrm{N}, 18^{\circ} \mathrm{W}$. DeepSea Res 40:1793-1814

Vors N, Buck KR, Chavez FP, Eikrem W, Hansen LE, Ostergaard JB, Thomsen HA (1995) Nanoplankton of the equatorial Pacific with emphasis on the heterotrophic protists. Deep-Sea Res II 42:585-602

Walsh JJ (1975) A spatial simulation model of the Peru upwelling ecosystem. Deep-Sea Res 22:201-236

Walsh JJ (1976) Herbivory as a factor in patterns of nutrient utilization in the sea. Limnol Oceanogr 21:1-13

Wlodarczyk E, Durbin AG, Durbin EG (1992) The effect of temperature upon lower feeding thresholds, gut evacuation rate, and diel feeding behavior in the marine copepod Acartia hudsonica Pinhey. Mar Ecol Prog Ser 85:93-106

Wroblewski JS, O'Brien JJ (1976) A spatial model of phytoplankton patchiness. Mar Biol 35:161-175

Submitted: November 25, 1998; Accepted: August 9, 1999 Proofs received from author(s): February 8,2000 